\title{
THE AUGMENTED REALITY IN THE EDUCATIONAL SPHERE OF STUDENT OF DEGREE IN CHILHOOD EDUCATION. CASE STUDY
}

\author{
LA REALIDAD AUMENTADA EN LA ESFERA EDUCATIVA DEL \\ ALUMNADO DE GRADO DE EDUCACIÓN INFANTIL. ESTUDIO DE \\ CASO
}

\author{
Dra. Verónica Marín Díaz \\ vmarin@uco.es \\ Universidad de Córdoba, Facultad de Ciencias de la Educación, \\ Dpto. de Educación. Avda. San Alberto Magno s/n, 14004-Córdoba, España
}

\begin{abstract}
The Augmented Reality presents itself in this last decade as an emerging technology that will promote the redesign of new educational methodologies. This research presented here brings forward the value that the pre service teachers have about this, inside the teaching action with children from 3 to 6 years. Using a descriptive and inferential study and using a questionnaire create ad hoc, composed by 31 items, of which, 3 referring to descriptive variables of sample and the remaining 28 gived answered to the objectives of the study. The simple was conformed by the student of Grade of Childhood education in the University of Cordova. The principal result is that AR can be a useful tool in the childhood education, enhancing the creativity of pupils, and the communication between them. Therefore we can conclude that their inclusion in the classroom methodology will revert positively in the teaching and learning process of children.

Keywords: Augmented Reality, higher education, university student.
\end{abstract}

Resumen: La realidad aumentada se presenta en ésta última década como una tecnología emergente que propiciará el rediseño de nuevas metodologías educativas. El estudio que aqui se presenta trae a la palestra el valor que los maestros en formación tienen sobre esta dentro de la acción docente con niños de 3 a 6 años. Empleando un diseño descriptivo e inferencial y empleando para ello un cuestionario creado ad hoc, conformado por 31 items, de los cuales, 3 de ellos referidos a las variables descriptivas de la muestra, y los 28 restantes daban respuesta a los objetivos del estudio. La muestra estaba constituida por estudiantes de Grado de Educación Infantil de la Universidad de Córdoba. El principal resultado alcanzado es que la RA puede ser una herramienta útil en la etapa de educación infantil, potenciando la creatividad de los estudiantes, la comunicación entre estos. Por tanto podemos concluir que su inclusión en la metodología de aula revertirá de forma positiva en el proceso de enseñanza y aprendizaje de los niños.

Palabras clave: Realidad Aumentada, educación superior, alumno universitario.

$$
-7-
$$

Píxel-Bit. Revista de Medios y Educación. No 51 Julio 2017. ISSN: 1133-8482. e-ISSN: 2171-7966. doi: http://dx.doi.org/10.12795/pixelbit.2017.i51.01 


\section{Introduction.}

The evolution of information and communication technologies (from here on ICT) implies that their sphere of activity has become more important in the various times in which they are employed by different individuals.

As for the education sphere, in the last decade their use has meant that the classrooms have become imbued in a process of constant re-definition, which implies that the teacher must be trained, or in other words, they must be in a constant process of retraining so that these technologies reach the student and be able to prove, in a few cases, that they are or not, viable in the education sphere.

The appearance of state-of-the-art technology, for example, Virtual Reality and Augmented Reality, has resulted in their validity for training to be questioned. However, both empirical and research contributions that are currently being developed have shown that their versatility allows for making learning more real (Prendes, 2015). This article presents the results of a case study of Infant Education teachers' evaluation of the new tools, more specifically, on the use of Augmented Reality in this schooling stage.

\section{Augmented Reality in the educational} sphere.

Fabregat (2012) has mentioned that Augmented Reality (from now on AR), provides a visual guide that allows the carrying out of an activity or task. Under this premise, the educational considerations of this tool could be exclusive, although it could be extrapolated to other social, scientific, economic areas of the individual, and as referring to the training sphere, its openness and willingness are latent.

There are many research studies of different nature that underscore the relationship AR-education, such as the work by Garay, Tejada and Maíz (2017) with Master's students, Barroso and Gallego (2017) with university students enrolled in the Education Degree, or the study by Crandall et al., (2015) which referred to its possibilities of use in matters such as Food Technology; for the teaching of math (Kaufman, Steinbugk, Dunser and Gluck, 2005), physics (Lin, Duh, Li, Wong \& Tsi, 2013; Chang, Wu \& Hsu, 2016) and anatomy (Citardí, Agdetoba, Bigas \& Luang, 2016). In children's education we find the work by Yilmaz (2016); in learning of a second language (Morales, Benítez, Silvia, Altamirano and Mendoza, 2015), and within second languages, we find the work by Hung, Chen and Huang (2016), who endorsed its use for the teaching and learning of Chinese characters. Lastly, we find various works that reflect it great usefulness in Architecture degrees (Redondo, Sánchez, Moya, \& Regot, 2012). All of these works endorse the conceptualization of AR given by Garnica and Calderón (2015, p.61), understanding it as «a view through a technological device combining the real world with virtual elements to obtain a mixed reality in real time». Beginning with this, we can specify that the main advantages of its use in the academic sphere revolve around: increases the student's motivation and interest for their own learning, enhances their playful learning, enables interaction in real time with the reality being studied, it also combines cognition with physical experience, and complements the perception, view and interaction that one has with the real world; it stimulates perception

$$
-8-
$$




\begin{tabular}{|c|c|}
\hline & Alfa \\
\hline Item 1 Augmented Reality enables the development of infant education & .889 \\
\hline Item 2 Augmented Reality enables the development of inclusive education & .890 \\
\hline Item 3 Augmented Reality fosters creativity & .897 \\
\hline Item 4 Augmented Reality enables collaborative work & .910 \\
\hline Item 5 Augmented Reality enables cooperative work & .887 \\
\hline Item 6 Augmented Reality enables group work & .886 \\
\hline Item 7 Augmented Reality facilitates real learning of the content & .887 \\
\hline Item 8 Augmented Reality fosters teaching through experimentation & .888 \\
\hline Item 9 Augmented Reality fosters teaching through free discovery & .886 \\
\hline Item 10 Augmented Reality can be used by persons with visual impairments & .887 \\
\hline Item 11 Augmented Reality can be used by persons with motor difficulties & .889 \\
\hline Item 12 Augmented Reality can be used by persons with psychological difficulties & .882 \\
\hline Item 13 Augmented Reality can be used by persons with hearing difficulties & .890 \\
\hline Item 14 Augmented Reality can foster the transversal teaching of content & .888 \\
\hline Item 15 Augmented Reality fosters intercultural learning & .887 \\
\hline Item 16 Augmented Reality facilitates the comprehension of curricular content & .885 \\
\hline Item 17 Augmented Reality complements the curricular content explained in class & .885 \\
\hline Item 18 Augmented Reality needs great technological support for its use in the classroom & .888 \\
\hline Item 19 Augmented Reality facilitates communication between students and teachers & .888 \\
\hline Item 20 Augmented Reality facilitates communication between students & .887 \\
\hline Item 21 To use Augmented Reality, computer skills are needed & .890 \\
\hline Item 22 Augmented Reality is easy to use for the students & .890 \\
\hline Item 23 The use of Augmented Reality makes difficult the acquisition of content & .887 \\
\hline Item 24 Learning how to use Augmented Reality takes a long time & .886 \\
\hline Item 25 Augmented Reality can be used by persons with high abilities & .892 \\
\hline Item 26 Augmented Reality fosters multicultural learning & .894 \\
\hline Item 27 Augmented Reality fosters the digital divide & .892 \\
\hline Item 28 Augmented Reality can be used to prevent situations of bullying at school & .893 \\
\hline
\end{tabular}

\section{Table 1. Cronbach's Alpha per item}

and helps with the comprehension of abstract concepts and contents, stimulates abstraction, enhances the development of cognitive, spatial and temporal abilities, and provokes intuitive and interactive learning (Álvarez, Delgado, Gimeno, Martín, Almaraz \& Ruiz, 2017; Barroso \& Gallego, 2017; Bujak, Radu, Catrambone, MacIntyre, Zheng and Golubski, 2013; Chen, Lee \& Lin, 2016; Coimbra, Cardoso and Mateus, 2015; CozarGuiérrez and Sáenz-López, 2017; Dunleavy \& Dede, 2014; Fracchia, Alonos and Martíns, 2015; Kraut \& Jekmié, 2013; Marín, 2016, 2017; Zak, 2014).
However, just as with anything, it also has aspects that could be used to question its viability and usability in these types of environments. These revolve around wireless connection failures in the education centers, scarce economic resources for having digital material available, lack of teacher's training for its interweaving with educational practices, students do not develop abilities but are instead distracted, need a great amount of time in the classroom in order to use it...(Álvarez et al, 2017; Cabero \& Barroso, 2016a, 2016b; Chiang, Yang \& Hwang 2014a, 2014b; Cubillo, Martín, Castro \& Colmenar, 2014; Durrall et al, 2012; Fox, 2010; Furió,

$$
-9-
$$

Píxel-Bit. Revista de Medios y Educación. $N^{\circ} 51$ Julio 2017. ISSN: 1133-8482. e-ISSN: 2171-7966. doi: http://dx.doi.org/10.12795/pixelbit.2017.i51.01 
González-Gancedo, Juan, Seguí \& Costa, 2013; Gavish, Gutierrez, Webel, Rodríguez, Peveri, Bockholt \& Franco 2015; Marín, 2016, 2017; Muñoz-Cristobal, Jorrin-Abellan, Asensio-Perez, Martínez-Mones, Prieto \& Dimitriadis, 2015; Nadolny, Woolfiey, Prelott \& Kahn, 2013).

As a consequence, the questions to be asked are: Does AR has or possess educational value?, and, Will its use in areas such as inclusive education be a latent reality?.

\section{Methods.}

Through the use of an ex post facto research method, with a descriptive and correlational design taking into account the classification by Mateo (2012, pg. 196), the research objectives and the hypothesis to be verified were determined.

The objective used for this research came from the general objective 1, designed for the RAFODIUM project (RAFODIUM, http:// intra.sav.us.es/proyectorafodiun/) from Figure 1. Sample distribution according to agewhich this study arose from. This was: To evaluate the possibilities and potential offered by different software used for the creation of technological environments under the architecture of Augmented Reality so that it could be used in university training contexts. Starting with this, the following, more specific objectives were proposed:

1. To determine if university students enrolled in the Infant Education Degree believe that Augmented Reality possesses educational value,

2. To establish the value of Augmented Reality as a curricular tool for infant education.

3. Determine the possible inclusive value of Augmented Reality.

The following starting hypotheses were posed:

H1: There are gender differences in gender when taking into account the educational value of Augmented Reality in Infant Education in favor of men.

H2: The younger students believe that Augmented Reality can be used as a resource that supports curricular development in Infant Education.

\subsection{Instrument Design}

For data gathering, an ad hoc questionnaire was designed. It was comprised of 31 items, where the first 3 corresponded to variables of identification (gender, age and the digital devices possessed by the students, -Tables, portable

\begin{tabular}{lcc}
\cline { 2 - 3 } & $\begin{array}{c}\text { Cronbach's } \\
\text { Alpha }\end{array}$ & $\begin{array}{c}\text { Total Variance } \\
\text { Explained }\end{array}$ \\
\hline Dimension 1 & .890 & 34.804 \\
Dimension 2 & .886 & 8.866 \\
Dimension 3 & .852 & 6.827 \\
Dimension 4 & .867 & 5.369 \\
Dimension 5 & .845 & 4.912 \\
Dimension 6 & .896 & 4.627 \\
Dimension 7 & .877 & 3.701 \\
\hline
\end{tabular}

Table 2. Alpha and Total Variance Explained

$$
-10-
$$




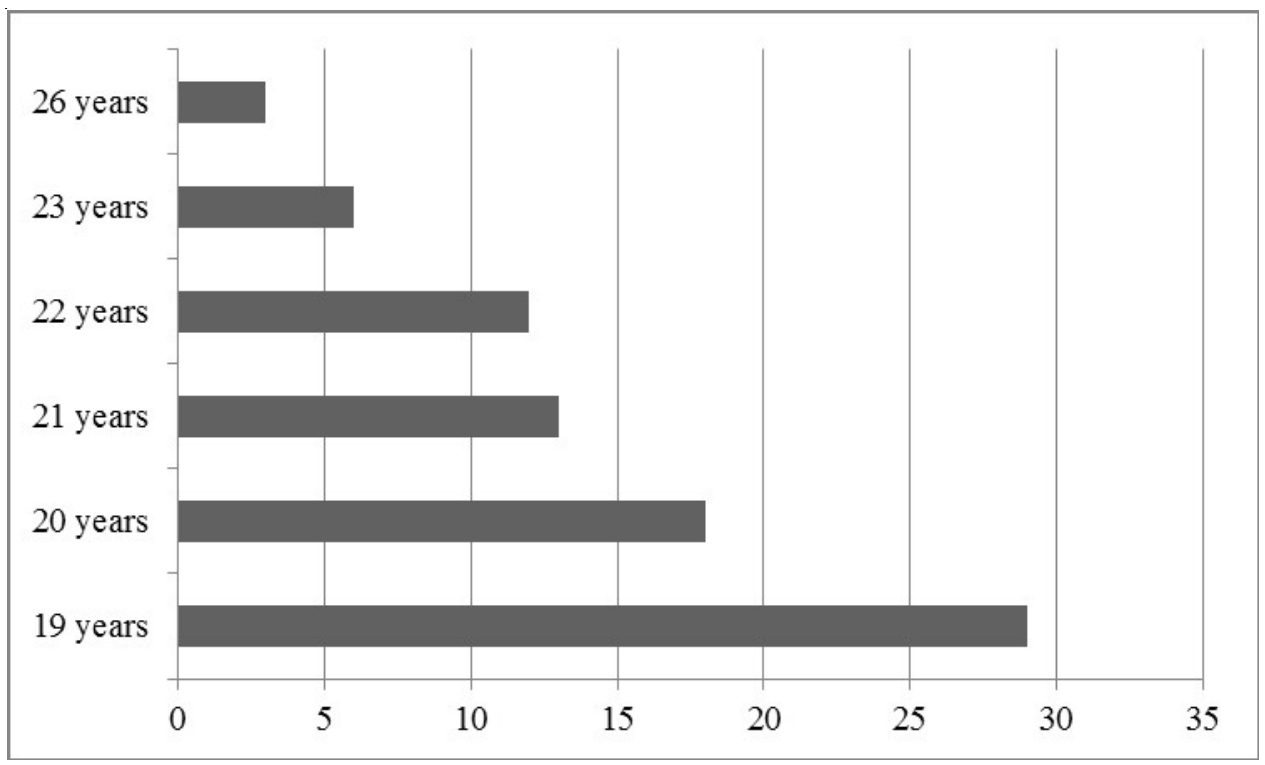

Figure 1. Sample distribution according to age

computer, Smartphone, desktop computer-), and the next 28 corresponded to independent variables, which were to be used for answering the objectives and hypotheses of the research work. The response scale of the first set were nominal, and of the second set it was a Likert-type scale, where 1 was completely disagree, and 5 completely agree.

After applying the Cronbach's Alpha test, we verified that the instrument's reliability was very high (0.893), taking into account the contributions by Mateo (2012). Likewise, in order to verify if the instrument maintained this reliability, the test was also applied to each item in the questionnaire (see table 1). The results for Alpha oscillated between 0.882 and 0.910 , so we can attest that the instrument had all the conditions of reliability for its subsequent use.

To verify the construct validity of the instrument, a Barlett's Sphericity test was applied (approximate Chi-square 1055.906 and significance values 0.000), and the KaiserMeyer-Olkin index was calculated as well $(\mathrm{KMO}=0.786)$. The test results showed the existence of 7 factors that explained 69.106 of the variance, which corroborated the instrument's consistency.

\subsection{Population and sample}

The starting population in this study was the set of students enrolled in the course Media Education and Didactic Applications of the ICT taught in the second year of the Infant Education Degree at the University of Cordoba.

$91.4 \%$ of the participants were women, and $8.6 \%$ of men. As for their studies prior to being admitted to the degree, $93.9 \%$ had a high school education/university entrance exam, 4.9 had higher education, while $1.2 \%$ had other studies. The age results showed

$-11-$

Píxel-Bit. Revista de Medios y Educación. $N^{o} 51$ Julio 2017. ISSN: 1133-8482. e-ISSN: 2171-7966. doi: http://dx.doi.org/10.12795/pixelbit.2017.i51.01 


\begin{tabular}{|c|c|c|c|c|c|c|c|c|c|c|c|c|}
\hline & \multicolumn{2}{|c|}{1} & \multicolumn{2}{|c|}{2} & \multicolumn{2}{|c|}{3} & \multicolumn{2}{|c|}{4} & \multicolumn{2}{|c|}{5} & \multirow[b]{2}{*}{ M } & \multirow[b]{2}{*}{ SD } \\
\hline & f. & $\%$ & f. & $\%$ & f. & $\%$ & f. & $\%$ & f. & $\%$ & & \\
\hline Item 1 & - & - & - & - & - & - & 56 & 69.1 & 25 & 30.9 & 4.31 & .465 \\
\hline Item 2 & - & - & 2 & 2.5 & 10 & 12.3 & 49 & 60.5 & 20 & 24.7 & 4.07 & .685 \\
\hline Item 3 & 3 & 3.8 & 1 & 1.3 & 2 & 2.5 & 39 & 48.8 & 35 & 43.8 & 4.28 & .886 \\
\hline Item 4 & 9 & 11.1 & 2 & 2.5 & 23 & 28.4 & 47 & 58 & - & - & 3.33 & .975 \\
\hline Item 5 & & & 3 & 3.7 & 16 & 19.8 & 50 & 61.7 & 12 & 14.8 & 3.88 & .696 \\
\hline Item 6 & 1 & 1.2 & 3 & 3.7 & 17 & 21 & 48 & 59.3 & 12 & 14.8 & 3.83 & .771 \\
\hline Item 7 & & & - & - & 10 & 12.3 & 44 & 54.3 & 27 & 33.3 & 4.21 & .646 \\
\hline Item 8 & & & - & - & 5 & 6.2 & 46 & 56.8 & 30 & 37 & 4.31 & .584 \\
\hline Item 9 & 1 & 1.2 & - & - & 8 & 9.9 & 46 & 56.8 & 25 & 30.9 & 4.19 & .658 \\
\hline Item 10 & & & 10 & 12.3 & 19 & 23.5 & 37 & 45.7 & 14 & 17.3 & 3.69 & .908 \\
\hline Item 11 & & & 1 & 1.2 & 14 & 17.3 & 49 & 60.5 & 17 & 21 & 4.01 & .661 \\
\hline Item 12 & & & 5 & 6.4 & 21 & 26.9 & 37 & 47.4 & 15 & 19.2 & 3.79 & .827 \\
\hline Item 13 & & & 1 & 1.2 & 3 & 3.7 & 40 & 49.4 & 37 & 45.7 & 4.40 & .626 \\
\hline Item 14 & & & 1 & 1.2 & 8 & 9.9 & 49 & 60.5 & 23 & 28.4 & 4.16 & .641 \\
\hline Item 15 & & & - & - & 15 & 18.5 & 47 & 58 & 19 & 23.5 & 4.05 & .650 \\
\hline Item 16 & & & - & - & 13 & 16 & 49 & 60.5 & 19 & 23.5 & 4.07 & .628 \\
\hline Item 17 & & & - & - & 1 & 16 & 43 & 53.1 & 23 & 28.9 & 4.13 & .667 \\
\hline Item 18 & & & - & - & 17 & 21 & 41 & 50.6 & 23 & 28.4 & 4.07 & .703 \\
\hline Item 19 & & & 5 & 6.2 & 17 & 21 & 43 & 53.1 & 15 & 18.5 & 3.85 & .797 \\
\hline Item 20 & & & & & 12 & 14.8 & 49 & 60.5 & 20 & 24.7 & 4.10 & .625 \\
\hline Item 21 & - & - & - & - & 5 & 6.2 & 50 & 61.7 & 26 & 32.1 & 4.26 & .565 \\
\hline Item 22 & - & - & 11 & 13.8 & 5 & 6.3 & 39 & 48.8 & 25 & 31.9 & 3.98 & .968 \\
\hline Item 23 & 1 & 1.2 & 3 & 3.7 & 12 & 14.8 & 43 & 53.1 & 22 & 27.2 & 4.01 & .829 \\
\hline Item 24 & 1 & 1.2 & 4 & 4.9 & 7 & 8.6 & 43 & 53.1 & 26 & 32.1 & 4.10 & .846 \\
\hline Item 25 & - & - & 8 & 9.9 & 6 & 7.4 & 42 & 51.9 & 25 & 30.9 & 4.04 & .887 \\
\hline Item 26 & - & - & 7 & 8.6 & 12 & 14.8 & 47 & 58 & 15 & 18.5 & 3.86 & .818 \\
\hline Item 27 & 4 & 4.9 & 24 & 29.6 & 11 & 13.6 & 31 & 38.3 & 11 & 13.6 & 3.26 & 1.170 \\
\hline Item 28 & 1 & 1.2 & 21 & 25.9 & 27 & 33.3 & 19 & 23.5 & 13 & 16 & 3.27 & 1.061 \\
\hline
\end{tabular}

Table 3. Descriptive study

that most of the sample were 19 years old, (43.2\%), Tablet, Smartphone and portable followed those aged 20 and 21 .

As for the devices they possessed, the computer $(30.9 \%)$, with a minority $(1.2 \%)$ owning a Tablet, Smartphone and desktop participants indicated owning a Tablet, computer, only a desktop computer or this Smartphone, portable and desktop computer last and a Tablet.

$-12-$

Píxel-Bit. Revista de Medios y Educación. $N^{o} 51$ Julio 2017. ISSN: 1133-8482. e-ISSN: 2171-7966. doi: http://dx.doi.org/10.12795/pixelbit.2017.i51.01 


\begin{tabular}{|c|c|c|c|c|c|c|}
\hline & Gender & $\mathrm{N}$ & Mean & SD & $\mathrm{F}$. & SIG. \\
\hline \multirow[t]{2}{*}{ Item 1} & Men & 7 & 4.43 & .535 & \multirow{2}{*}{1.016} & \multirow{2}{*}{.317} \\
\hline & Women & 74 & 4.30 & .460 & & \\
\hline \multirow[t]{2}{*}{ Item 2} & Men & 7 & 3.86 & .378 & \multirow{2}{*}{1.585} & \multirow{2}{*}{.212} \\
\hline & Women & 74 & 4.09 & .706 & & \\
\hline \multirow[t]{2}{*}{ Item 3} & Men & 7 & 3.00 & 2.000 & \multirow{2}{*}{82.198} & \multirow{2}{*}{.000} \\
\hline & Women & 73 & 4.40 & .595 & & \\
\hline \multirow[t]{2}{*}{ Item 4} & Men & 7 & 3.29 & .756 & \multirow{2}{*}{.564} & \multirow{2}{*}{.455} \\
\hline & Women & 74 & 3.34 & .997 & & \\
\hline \multirow[t]{2}{*}{ Item 5} & Men & 7 & 3.57 & 1.134 & \multirow{2}{*}{5.847} & \multirow{2}{*}{.018} \\
\hline & Women & 74 & 3.91 & .645 & & \\
\hline \multirow[t]{2}{*}{ Item 6} & Men & 7 & 3.00 & 1.291 & \multirow{2}{*}{13.537} & \\
\hline & Women & 74 & 3.91 & .666 & & .000 \\
\hline Item 7 & Men & 7 & 3.86 & .900 & & 105 \\
\hline & Women & 74 & 4.24 & .615 & 2.095 & .105 \\
\hline Item 8 & Men & 7 & 3.86 & .378 & & \\
\hline & Women & 74 & 4.35 & .584 & 0.250 & .000 \\
\hline Item 9 & Men & 7 & 4.00 & .577 & & 153 \\
\hline & Women & 73 & 4.21 & .666 & 2.000 & .153 \\
\hline Item 10 & Men & 7 & 3.43 & .535 & & \\
\hline & Women & 73 & 3.71 & .935 & 1.188 & .185 \\
\hline Item 11 & Men & 7 & 4.29 & .488 & & 925 \\
\hline & Women & 74 & 3.99 & .672 & .009 & .925 \\
\hline Item 12 & Men & 7 & 3.71 & .951 & & \\
\hline & Women & 71 & 3.80 & .821 & .804 & $.3 / 3$ \\
\hline Item 13 & Men & 7 & 4.57 & .535 & & \\
\hline & Women & 74 & 4.38 & .635 & .315 & $.5 / 0$ \\
\hline Item 14 & Men & 7 & 4.57 & .535 & 051 & 822 \\
\hline & Women & 74 & 4.12 & .640 & 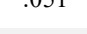 & .022 \\
\hline Item 15 & Men & 7 & 3.86 & .378 & 1773 & 004 \\
\hline & Women & 74 & 4.07 & .669 & 1.115 & .004 \\
\hline Item 16 & Men & 7 & 3.57 & .787 & 1962 & 165 \\
\hline & Women & 74 & 4.12 & .596 & 1.902 & .100 \\
\hline Item 17 & Men & 7 & 3.71 & .951 & 4559 & \\
\hline & Women & 72 & 4.17 & .628 & 4.559 & .000 \\
\hline Item 18 & Men & 7 & 3.86 & .690 & 074 & 786 \\
\hline & Women & 74 & 4.09 & .706 & .014 & .100 \\
\hline Item 19 & Men & 7 & 4.00 & .577 & 2543 & 005 \\
\hline & Women & 73 & 3.84 & .817 & 2.543 & .005 \\
\hline Item 20 & Men & 7 & 3.57 & .535 & 038 & 846 \\
\hline & Women & 74 & 4.15 & .612 & .050 & .040 \\
\hline Item 21 & Men & 7 & 4.14 & .378 & 4.418 & \\
\hline & Women & 74 & 4.27 & .580 & 4.410 & .059 \\
\hline Item 22 & Men & 7 & 3.86 & 1.215 & 2046 & 157 \\
\hline & Women & 73 & 3.99 & .950 & 2.040 & I \\
\hline Item 23 & Men & 7 & 3.29 & .951 & 547 & 462 \\
\hline & Women & 74 & 4.08 & .790 & $.54 /$ & .402 \\
\hline Item 24 & Men & 7 & 3.86 & .900 & 070 & \\
\hline & Women & 74 & 4.12 & .843 & .070 & .193 \\
\hline Item 25 & Men & 7 & 3.29 & 1.254 & 5.474 & .002 \\
\hline & Women & 74 & 4.11 & .820 & $3.4 / 4$ & .002 \\
\hline Item 26 & Men & 7 & 3.86 & .378 & 2634 & 109 \\
\hline & Women & 74 & 3.86 & .849 & 2.034 & .109 \\
\hline Item 27 & Men & 7 & 3.14 & .900 & & 112 \\
\hline & Women & 74 & 3.27 & 1.197 & 2.500 & .112 \\
\hline Item 28 & Men & 7 & 2.86 & 1.215 & & 567 \\
\hline & Women & 74 & 3.31 & 1.046 & (1) & .001 \\
\hline
\end{tabular}

Table 4. Student's t-test according to gender

$-13-$

Píxel-Bit. Revista de Medios y Educación. $N^{o} 51$ Julio 2017. ISSN: 1133-8482. PIXEL e-ISSN: 2171-7966. doi: http://dx.doi.org/10.12795/pixelbit.2017.i51.01 


\begin{tabular}{|c|c|c|c|c|c|c|}
\hline (I) age & (J) age & $\begin{array}{c}\text { Differences between } \\
\text { means (I-J) }\end{array}$ & $\begin{array}{c}\text { Standard } \\
\text { error }\end{array}$ & Sig. & $\begin{array}{l}\text { Lower } \\
\text { limit }\end{array}$ & $\begin{array}{l}\text { Upper } \\
\text { limit }\end{array}$ \\
\hline \multirow{5}{*}{19} & \multirow{4}{*}{ 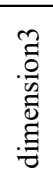 } & & & .995 & -.62 & .89 \\
\hline & & -.324 & .245 & .882 & -1.16 & .51 \\
\hline & & -.279 & .252 & .941 & -1.14 & .58 \\
\hline & & .305 & .329 & .973 & -.82 & 1.43 \\
\hline & ت7 26 & $2.138^{*}$ & .445 & .001 & .62 & 3.66 \\
\hline \multirow{5}{*}{20} & \multirow{4}{*}{ 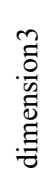 } & -.138 & .220 & .995 & -.89 & .62 \\
\hline & & -.462 & .267 & .703 & -1.37 & .45 \\
\hline & & -.417 & .274 & .802 & -1.35 & .52 \\
\hline & & .167 & .346 & .999 & -1.02 & 1.35 \\
\hline & $=26$ & $2.000^{*}$ & .458 & .004 & .44 & 3.56 \\
\hline \multirow{5}{*}{21} & \multirow{4}{*}{ 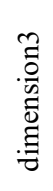 } & .324 & .245 & .882 & -.51 & 1.16 \\
\hline & & .462 & .267 & .703 & -.45 & 1.37 \\
\hline & & .045 & .294 & 1.000 & -.96 & 1.05 \\
\hline & & .628 & .362 & .699 & -.61 & 1.87 \\
\hline & $=26$ & $2.462^{*}$ & .470 & .000 & .85 & 4.07 \\
\hline \multirow{5}{*}{22} & m 19 & .279 & .252 & .941 & -.58 & 1.14 \\
\hline & \multirow{3}{*}{ 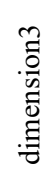 } & .417 & .274 & .802 & -.52 & 1.35 \\
\hline & & -.045 & .294 & 1.000 & -1.05 & .96 \\
\hline & & .583 & .367 & .772 & -.67 & 1.84 \\
\hline & $\exists \quad 26$ & $2.417^{*}$ & .474 & .000 & .80 & 4.04 \\
\hline \multirow{5}{*}{23} & \multirow{4}{*}{ 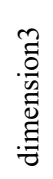 } & -.305 & .329 & .973 & -1.43 & .82 \\
\hline & & -.167 & .346 & .999 & -1.35 & 1.02 \\
\hline & & -.628 & .362 & .699 & -1.87 & .61 \\
\hline & & -.583 & .367 & .772 & -1.84 & .67 \\
\hline & "ᄏ 26 & $1.833^{*}$ & .519 & .038 & .06 & 3.61 \\
\hline \multirow{5}{*}{26} & m 19 & $-2.138^{*}$ & .445 & .001 & -3.66 & -.62 \\
\hline & \multirow{3}{*}{ 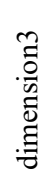 } & $-2.000^{*}$ & .458 & .004 & -3.56 & -.44 \\
\hline & & $-2.462^{*}$ & .470 & .000 & -4.07 & -.85 \\
\hline & & $-2.417^{*}$ & .474 & .000 & -4.04 & -.80 \\
\hline & $=23$ & $-1.833^{*}$ & .519 & .038 & -3.61 & -.06 \\
\hline
\end{tabular}

Table 5. ANOVA according to age

\section{Results.}

\subsection{Descriptive study.}

The results of the descriptive study (see table 3) show that the participating students mostly sided themselves with a position of agreement, followed by being in complete agreement and indifferent. However, items 27 and 28 were notable, as the students placed themselves between agree and disagree when referring to the creation of a digital divide due to the use of Augmented Reality in the educational sphere and in disagreement and indifferent when faced with the possibility that this technology could help in preventing school bullying.

\subsection{Inferential Study.}

The Student's t-test for independent samples using gender as the selection

$-14-$

Píxel-Bit. Revista de Medios y Educación. No 51 Julio 2017. ISSN: 1133-8482. e-ISSN: 2171-7966. doi: http://dx.doi.org/10.12795/pixelbit.2017.i51.01 
variable showed the existence of statisticallysignificant differences in items 3, 6, 8, 15, 19 and 25 in favor of the women, while in the rest of the items, no differences were found in favor of any of the genders.

The results from the ANOVA followed by Scheffe's test showed that there were no differences in item 24 (see table 5). These indicated that the younger students believed that AR facilitated communication between students, as compared to the older set who thought otherwise.

\section{Discussion and conclusions.}

Augmented Reality, defined as an emergent technology by the most up-to-date Horizon reports (Durral, Gros, Maina, Johnson \& Adams, 2012; Johnson, Adams, Cummins, Estrada, Freeman \& Hall, 2016), is little by little becoming included in the classroom methodologies in different educational levels (Solano, Casas \& Guevara, 2015; Yilmaz, Kucuk \& Goktas, 2016; Barroso \& Gallego, 2017; Garay, Tejada, Maíz, 2017).

The research study undertaken has shown that the participating university students enrolled in the Infant Education degree believed that AR has educational value, in agreement with results by Marín $(2016,2017)$, Barroso \& Gallego (2017), Garay, Tejada \& Castaño (2017). In this line, their evaluations on the great possibilities AR has for developing learning of the curriculum are found, highlighting an element that is highly valued in this educational stage such as creativity. This is in agreement with the results reached by Yuen, Yaoyuneyong and Johnson (2011), Chen and Tsai (2012), Wei, Weng, Liu and Wong, (2015) and Marín (2016, 2017), experimentation (De Pedro and Martínez, 2012; Wei et al. (2015), as well as communication between students (Zarraonadia, Aedo, Díaz \& Montero 2013; Martín-Gutiérrez, Fabiani, Benesova, Meneses \& Mora, 2015).

As for the third objective (Determine the possible inclusive value of Augmented Reality), we could conclude that its positioning was positive, as just as the work by Cozar et al (2015), they contemplated the possibility of its use by disabled students, especially those who have high abilities.

Lastly, it should be noted that H1 should be rejected, as differences in favor of the men were not found. However, $\mathrm{H} 2$ is accepted but only partially, as it was only reflected in one item, number 24.

Ultimately, and after this research study, we can conclude that Augmented Reality could be a very useful tool in the infant education stage.

\section{Funding sources}

This work is framed within the $\mathrm{R}+\mathrm{D}$ research project financed by the Spanish Ministry of Economy and Competitiveness named: «Augmented reality for increasing teaching. Design, production and evaluation of augmented reality programs for university training» (EDU-5746-P-Proyecto Rafodiun).

\section{Bibliographic references}

Álvarez, S., Delgado, L., Gimeno, M. Á., Martín, T., Almaraz, F. \& Ruiz, C. (2017). The Educational Sandbox: Augmented Reality a new resource for teaching. EDMETIC, Journal of Media Literacy and ICT, 6(1), 105123. Retrieved from http://www.uco.es/ ucopress/ojs/index.php/edmetic/article/ view/5810/5444

Barroso, J. M., \& Gallego, O. (2017). Learning resource production in Augmented

$-15-$

Píxel-Bit. Revista de Medios y Educación. $N^{o} 51$ Julio 2017. ISSN: 1133-8482. e-ISSN: 2171-7966. doi: http://dx.doi.org/10.12795/pixelbit.2017.i51.01 
Reality supported by education students. EDMETIC, Journal of Media Literacy and ICT, 6(1), 23-38. Retrieved from http:// www.uco.es/ucopress/ojs/index.php/ edmetic/article/view/5806/5440

Bujak, K. R., Radu, I., Catrambone, R., MacIntyre, B., Zheng, R., \& Golubski, G. (2013). A psychological perspective on augmented reality in the mathematics classroom. Computers \& Education, 68, 536544. doi:10.1016/j.compedu.2013.02.017.

Cabero, J., \& Barroso, J. (2016a). Educational possibilities of Augmented Reality. In J, Cabero y F. García (coords.), Augmented reality: technologies by the training (pp.97-112). Madrid: Síntesis.

Cabero, J., \& Barroso, J. (2016b). Educational possibilities of Augmented Reality. NAER, Journal of New Approaches in Educational Research, 5(1), 44-50. doi: https://doi.org/10.7821/naer.2016.1.140

Chang, H.-Y., Wu, H.-K., \& Hsu, Y.-S. (2016). Integrate a mobile augmented reality activity to contextualize student learning of a socio scientific issue. British Journal of Educational Technology, 44(3), E95-E99, doi:10.1111/j.1467-8535.2012.01379.x.

Chen, C.H., Lee, I.-J. \& Lin, L.-Y. (2016). Augmented reality-based video-modeling storybook of nonverbal facial cues for children with autism spectrum disorder to improve their perceptions and judgments of facial expressions and emotions. Computers and Human Behaviour, 16, 477-485. doi:10.1016/j.chb.2015.09.033.

Cheng, K.-H. \& Tsai, C.-C. (2014). Children and parents' reading of an augmented reality picture book: Analyses of behavioural patterns and cognitive attainment. Computers \& Education, 72, 302-314. doi:10.1016/j.compedu.2013.12.003.
Chiang, T. H., Yang, S. J., \& Hwang, G.-J. (2014a). Students' online interactive patterns in augmented reality-based inquiry activities. Computers \& Education, 78, 97-108. doi: 10.1016/j.compedu.2014.05.006.

Chiang, T.-H.-C., Yang, S.-J.-H., \& Hwang, G.-J. (2014b). An Augmented Reality-based Mobile Learning System to Improve Students' Learning Achievements and Motivations in Natural Science Inquiry Activities. Educational Technology \& Society, 17(4), 352-365. Retrieved from http:/ /www.ifets.info/journals/17_4/24.pdf

Citardi, M. J., Agbetoba, A., Bigcas, J.-L. \& Luong, A. (2016). Augmented reality for endoscopic sinus surgery with surgical navigation: a cadaver study. International Forum of Allergy \& Rhinology, 6(5), 523-528. doi:10.1002/alr.21702.

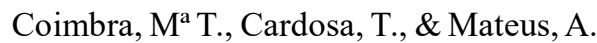
(2015). Augmented reality: an enhancer for higher education students in math's learning? Procedia Computer Science, 67, 332-339. doi: 10.1016/j.procs.2015.09.277.

Cózar, R., del Moya, M., Hernández, J.A., \& Hernández, J.R. (2015). Emerging Technologies in Social Sciences Teaching. An Experience Using Augmented Reality in Teacher Training. Digital Education Review, 27, 138-153. Retrieved from http:// revistes.ub.edu/index.php/der/article/ viewFile/11622/pdf

Cózar-Gutiérrez, R., \& Sáez-López, J. M. (2017). Augmented reality, projects in primary school: experiences and cases in Social Sciences. EDMETIC, Journal of Media Literacy and ICT, 6(1), 165-180. Retrieved from http://www.uco.es/ucopress/ojs/ index.php/edmetic/article/view/5813/5447

Crandall, P.G., Engler III, R. K., Beck, D. E., Killian, S. A., O’Bryan, C. A., Jarvis, N., \& Clausen, E. (2015). Development of an

$-16-$

Píxel-Bit. Revista de Medios y Educación. No 51 Julio 2017. ISSN: 1133-8482. e-ISSN: 2171-7966. doi: http://dx.doi.org/10.12795/pixelbit.2017.i51.01 
Augmented Reality Game to Teach Abstract Concepts in Food Chemistry. Journal of Food Science Education, 14(1), 18-23. DOI:10.1111/ 1541-4329.12048

de Pedro, J. \& Méndez, C. L. (2012). Augmented Reality: an alternative methodology in primary education in Nicaragua. IEEE-RITA, 7(2), 102-108. Retrieved from http://rita.det.uvigo.es/ $201205 / \mathrm{u} p 1$ o a d s / I E E E RITA.2012.V7.N2.A9.pdf

Dunleavy, M., \& Dede, C. (2014). Augmented reality teaching and learning. In J. Spector, M. Merrill, J. Elen \& M. Bishop (eds.), The handbook of research for educational communications and technology (pp.735-745). New York: Springer.

Durall, E., Gros, B., Maina, M. F., Johnson, L., \& Adams, S. (2012). Technological perspectivas: Higher Education in Latin America 2012-2017. Retrieved from http:// openaccess.uoc.edu/webapps/o2/handle/ 10609/17021

Fabregat, R. (2012). Combining Augmented Reality and Adaptive E-learning Platforms. Enl@ce: Venezuelan Journal of Information, Technology and Knowledge, 9(2), 69-78.

Fox, S. (2010). The importance of information and communication design for manual skills instruction with augmented reality. Journal of Manufacturing Technology Management, 21(2), 188-205. doi:10.1108/ 17410381011014369.

Fracchia, C.C., Alonso, A.C., \& Martins, A. (2015). Augmented Reality applied to the teaching of Natural Sciences. TE \& ET. 16, 715.

Furió, D., González-Gancedo, S., Juan, M.C., Seguí, I., \& Costa, M. (2013). The effects of the size and weight of a mobile device on an educational game. Computers \& Education, 64, 24-41.
Garay, U., Tejada, E., \& Maíz, I. (2017). Valuation of the Educational Objects with Augmented Reality: Experience with Posgraduates Students. Píxel-Bit. Journal of Mass and Educaction, 50, 19-31. doi: 10.12795/pixelbit.

Garnica, E., \& Calderon, J. A. F. (2015). Augmented Reality and Education. Journal Engineering, Mathematics and Information Sciences, 2(3). Retrieved from http:// ojs.urepublicana.edu.co/index.php/ ingenieria/article/view/238

Gavish, N., Gutiérrez, T., Webel, S., Rodríguez, J., Peveri, M., Bockholt, U., \& Franco, T. (2015). Evaluating virtual reality and augmented reality training for industrial maintenance and assembly tasks. Interactive Learning Environments, 23(6), 778-798.

Hung, Y.-H, Chen, C.-H., \& Huang, S.-W. (2016). Applying augmented reality to enhance learning: a study of different teaching materials. Journal of Computer Assisted Learning, December. doi:10.1111/ jcal.12173.

Johnson, L., Adams, S., Cummins, M., Estrada, V., Freeman, A., \& Hall, C. (2016). NMC Horizon Report: 2016 Higher Education Edition. Austin, Texas: The New Media Consortium. Retrieved from http:// blog.educalab.es/intef/wp-content/uploads/ sites/4/2016/03/Resumen_Horizon_U niversidad_2016_INTEF_mayo_2016.pdf

Kaufmann, H., Steinbugl, K., Dunser, A., \& Gluck, J. (2005). General training of spatial abilities by geometry education in augmented reality. Cyberpsychology \& Behavior, 8(4), 330.

Kraut, B., \& Jeknié, J. (2013). Improving education experience with augmented reality (AR). Retrieved from https:// www.researchgate.net/publication/

$-17-$

Píxel-Bit. Revista de Medios y Educación. $N^{\circ} 51$ Julio 2017. ISSN: 1133-8482. e-ISSN: 2171-7966. doi: http://dx.doi.org/10.12795/pixelbit.2017.i51.01 
277985946_Improving_education_exp erience_with_Augmented_Reality_AR

Lin, T. J., Duh, H. B. L., Li, N., Wang, H. Y., \& Tsai, C. C. (2013). An investigation of learners' collaborative knowledge construction performances and behavioural patterns in an augmented reality simulation system. Computers \& Education, 68, 314321. http://dx.doi.org/10.1016/ j.compedu.2013.05.011

Marín, V. (2016). Possibilities for the use of augmented reality in inclusive education. Case study. Essays, Journal of the Faculty of Education of Albacete, 31(2), 57-68.

Marín, V. (2017). Relations between Augmented Reality and education inclusive in Higher Education. Bordón, In press.

Martín-Gutiérrez, J., Fabiani, P., Benesova, W., Meneses, M.D., \& Mora, C. E. (2015). Augmented reality to promote collaborative and autonomous learning in higher education, Computers in Human Behavior, 51, 752-761. doi: 10.1016/j.chb.2014.11.093.

Mateo, J. (2012). Ex post-facto research, in R. Bisquerra (coord.), Educational Research Metodology, (pp.195-229). Madrid: La Muralla.

Morales, M., Benítez, C., Silva, D., Altamirano, M., \& Mendoza, H. M. (2016). Mobile application for learning English using augmented reality. Iberoamerican Journal of Academic and Educational Management Production, Retrieved from http:// www.pag.org.mx/index.php/PAG/article/ viewFile/513/552

Muñoz-Cristobal, J. A., Jorrin-Abellan, I. M., Asensio-Pérez, J. I., Martínez-Monés, A., Prieto, L. P., \& Dimitriadis, Y. (2015). Supporting teacher orchestration in ubiquitous learning environments: A study in primary education. Learning Technologies, IEEE Transactions on Learning, 8(1), 83-97.
Nadolny, L., Woolfrey, J., Pierlott, M., \& Kahn, S. (2013). SciEthics Interactive: science and ethics learning in a virtual environment Education Tech Research Dev, 61, 979-999. doi:10.1007/s11423-013-9319-0.

Prendes, C. (2015). Augmented Reality and education: analyse of practical experiences. Pixel Bit, Journal of Mass and Education, 46, 157-203. doi:10.12795/pixelbit.2015.146.12.

Redondo, E., Sánchez, A., Moya, J., \& Regot, J. (2012). The city as a digital classroom: teaching urbanism and architecture through Mobile Learning and augmented reality: a feasibility and case study ACE: Architecture, City and Environment, 19, 27-54.

Solano, C. A., Casas, J. F., \& Guevara, J. C. (2015). A Mobile Augmented Reality application for teaching the classication of Living Things to Primary School's Children. Ingeniery Journal, 20(1). Retrieved from http://revistas.udistrital.edu.co/ojs/ index.php/reving/article/view/8190/10285

Wei, X., Weng, D., Liu, Y., \& Wang, Y. (2015). Teaching based on augmented reality for a technical creative design course. Computers \& Education, 81, 221234.doi:10.1016/j.compedu.2014.10.017

Yilmaz, R. M.(2016). Educational magic toys developed with augmented reality technology for early childhood education. Computers in Human Behavior, 54, 240-248. doi:10.1016/j.chb.2015.07.040.

Yilmaz, R.M., Kucuk, S., \& Goktas, Y. (2016). Are augmented reality picture books magic or real for preschool children aged five to six. British Journal of Educational Technology. In preens. doi:10.1111/bjet.12452.

Yuen, S., Yaoyuneyong, G., \& Johnson, E. (2011). Augmented reality: An overview and five directions for AR in education. Journal

$-18-$

Píxel-Bit. Revista de Medios y Educación. No 51 Julio 2017. ISSN: 1133-8482. e-ISSN: 2171-7966. doi: http://dx.doi.org/10.12795/pixelbit.2017.i51.01 
of Educational Technology Development and Exchange, 4(1), 119-140.

Zak,_E. (2014). Do You Believe in Magic? Exploring the Conceptualization of Augmented Reality and its Implications For the User in the Field of Library and Information Science Information Technology And Libraries. Desembre, 23-50. Retrieved from https://ejournals.bc.edu/ojs/index.php/ ital/article/viewFile/5638/5185

Zarraonandia, T., Aedo, I., Díaz, P., \& Montero, A. (2013). An augmented lecture feedback system to support learner and teacher communication. British Journal of Educational Technology, 44(4), 616-628.

Fecha de recepción: 25-02-2017

Fecha de evaluación: 01-03-2017

Fecha de aceptación: 03-03-2017

- 19 -

Píxel-Bit. Revista de Medios y Educación. No 51 Julio 2017. ISSN: 1133-8482. e-ISSN: 2171-7966. doi: http://dx.doi.org/10.12795/pixelbit.2017.i51.01 